\title{
The Effectiveness of Quantitative Easing: Evidence from Japan
}

\author{
Roman Matousek $^{1,2}$, Stephanos T. Papadamou ${ }^{3}$, Aleksandar Šević ${ }^{4 *}$, Nickolaos G. \\ Tzeremes $^{5}$
}

\begin{abstract}
${ }^{1}$ Nottingham University Business School, University of Nottingham, Jubilee Campus, Nottingham NG8 1BB, United Kingdom.Email: Roman.Matousek@nottingham.ac.uk

${ }^{2}$ Othman Yeop Abdullah Graduate School of Business (OYAGSB), University Utara Malaysia, UUM, Sintok, Malaysia

${ }^{3}$ Department of Economics, University of Thessaly, 28th October Street, 78, 38333, Volos, Greece.E-mail: stpapada@uth.gr

4* Trinity Business School, Trinity College Dublin, University of Dublin, Dublin, Ireland, Email: sevica@tcd.ie, corresponding author

${ }^{5}$ Department of Economics, University of Thessaly, 28th October Street, 78, 38333, Volos, Greece.E-mail: bus9nt@econ.uth.gr
\end{abstract}

\begin{abstract}
This study contributes to current research on quantitative easing. We provide a novel analysis of the quantitative easing effectiveness as an unconventional monetary policy tool in Japan over the last two decades. The paper advances current research on quantitative easing by exploring quantitative easing through the prism of the monetary transmission mechanism. We examine the response of Japanese Regional Banks to the quantitative easing operations conducted by the Bank of Japan from the early 2000s till 2015. The analysis is performed within the framework of the bank lending channel under the unconventional monetary policy strategies. We find that small-sized regional banks underline the significant positive effect of quantitative easing on gross domestic product and inflation that works through the securities holdings and leverage preferences. Monetary authorities should pay particular attention to policies for such banks and banks with a high level of non-performing loans. Deposit growth after a quantitative easing shock is only present in large sized banks with low NPLs holdings.
\end{abstract}

JEL classification: G1; G21; G28; E52

Keywords: Quantitative easing; Financial institutions; NPLs; Panel VAR, Japan 


\section{Introduction}

In 2001, the Bank of Japan (BOJ) was the first Central Bank that implemented into its operational policy an unconventional monetary instrument - quantitative easing. This was seen as a direct reaction to the sluggish economy and the fact that standard monetary stimulus was exhausted. Quantitative Easing (QE) was viewed as a possible monetary policy instrument that could help to reverse a negative inflation rate and to overcome the problems of the liquidity trap.

The paper is underpinned by current research on QE effectiveness as an unconventional monetary policy tool in Japan over the last two decades. The study is based on the existing literature on QE that includes, for example, Yang and Zhou, 2016; Yang and Zhou, 2013; Girardin and Mousa, 2011; and Schenkelberg and Watzka, 2013 among others. Our focus is, however, focused on exploring QE through the prism of the monetary transmission mechanism. We examine the response of Japanese Regional Banks to the QE activities conducted by BOJ in the early 2000s and the analysed period includes the global financial crisis (GFC). The analysis is performed within the framework of the bank lending and asset pricing channels under the unconventional monetary policy strategies. We use Regional Banks since these banks play a crucial role in lending activities to small- and medium-sized firms that have significant constraints in accessing capital markets (Van Rixtel, 2002). Moreover, the Japanese Regional Banks provide a distinctive platform for the examination of the long-lasting effect of non-performing loans (NPLs) on the implementation and effectiveness of the adopted quantitative easing strategies. ${ }^{1}$

The contribution of the paper can be summarized as follows: Firstly, our study builds upon the previous theoretical models introduced by Tobin, 1970; Bernanke and Blinder, 1988; and recently Ramos-Tallada, 2015. Our model is based on the assumption of the existence of a competitive equilibrium in the loan market. We provide a unique decomposition of regional banks' total loan growth into demand and supply factors that drive loan growth. Such a disaggregation allows us to detect whether supply driven loan growth is accompanied by a significant increase in bank capital in order to absorb any significant losses in the future. Such an analysis could provide information about the sensitivity of financial systems to possible exposures of future

\footnotetext{
${ }^{1}$ Recently, Fukuyama, and Matousek (2017) show that Regional Banks have a large proportion of NPLs on their balance sheets, low capitalization and financial losses caused mainly by deteriorated balance sheets.
} 
exogenous negative shocks. This is valuable information for policymakers in terms of the adoption of bank recapitalization measures.

Secondly, we investigate the impact of QE thoroughly not only on supply and demand factors that drive loans but also on several other crucial bank decision parameters. These include securities and liquidity holdings, leverage ratio and deposits growth. As a result, we identify the banks' portfolio preferences between liquidity, securities holdings and lending after a QE shock. Thus, we distinguish between "real economy" and "financial economy" effects, and our analysis is unique in terms of answering the question whether bank liquidity passes to financial markets or the real Japanese economy. By exploring the impact of securities holdings and lending on economic activity, we may provide evidence of an active asset pricing channel and/or an active bank lending channel through the QE process (see, for example, Ugai, 2007; Krishnamurthy and Vissing-Jorgensen, 2011; Joyce and Spaltro, 2014). Thus, the investigation of Japanese banks' excess liquidity holdings implies increased risk aversion with a negative effect on economic activity. Such an analysis offers valuable information since it unveils how QE affects a balance sheet of Regional Banks, and thus the potential impact on the real economy. Furthermore, we also address the vital question of how QE affects banks of different size and different levels of NPLs (Gambacorta et al., 2014). This is of crucial importance, and the findings could direct the policy makers towards effective NPLs management policies.

Thirdly, in terms of methodological contribution, we apply for this kind of analysis for the first time a PVAR by including bank-level data. In our model, the decomposed loans are treated as an endogenous variable in a system allowing for timelag reactions. Recent studies use a single lending equation in the general form within the panel data context (Ramos-Tallada, 2015; Bowman et al., 2015). It is important to underline the fact that the adopted methodological framework of PVAR reveals and provides new insights (Iacoviello and Navarro, 2019) that could be hidden from the methodologies that have been adopted in previous research studies.

The paper is structured as follows. An overview of the Japanese monetary policy and banking since the middle 1980s is presented in section 2 . Section 3 contains a brief review of the relevant literature followed, in section 4, by a description of the data and the methodology employed herein. The analysis of the results is conducted in section 5 where the paper tries to provide plausible and tentative explanations for the different responses that it identifies. Finally, section 6 concludes the paper. 


\section{An overview of the Japanese monetary policy and banking since middle 1980s}

During the second half of the 1980s, Japan experienced a classic credit-induced real estate boom and financial assets' bubble. This bubble was fueled by a malicious spiral of rising asset prices, higher collateral value and increasing bank credit. The factors that caused this type of asset bubble are frequently listed: the increased competition among commercial banks due to financial reforms that diminish the bank's profit margin. That led banks to conduct riskier activities by expanding their lending to real estate and construction companies and non-bank financial institutions (Nakajima and Taguchi, 1995). The specific financial structure (Keiretsu) within the Japanese financial market put a veil on the growing problems within the real economy. A further factor was the fact that the strict financial regulation imposed on banks forced them to be mostly oriented on lending activities (Hamada, 1995).

Furthermore, the use of informal policy instruments and the presence of informal networks between monetary authorities and banks contributed also to the asset bubble. The administrative guidance regarding the lending policy, promulgated by the Ministry of Finance (MoF), was not very effective, most likely owing to a combination of political factors and the significant presence of $\mathrm{MoF}$ retirees on the boards of regional banks (Van Rixtel, 2002). Another serious problem was inadequate co-ordination between the MoF that used several informal macro monetary policy instruments that primarily affected the capital market, and the policy objectives of the BoJ focused on money markets. Furthermore, the 'bubble' was driven by the accommodative stance of Japanese monetary policy, partly caused by international exchange rate fluctuations and related pressure from the MoF (Hamada, 1995; Okina et al. 2000). Keeping the official discount rate at a historically low level of 2,5\% until the end of May 1989 resulted in the creation of excess liquidity, and enabled the banking industry to resort to excessive lending activity.

BoJ faced one of the most complex issues in the assessment of monetary policy, which is the co-existence of asset price 'bubbles' and price stability (Okina et al. 2000). However, in May 1989 inflationary pressures forced BoJ to adopt a restrictive monetary policy, which signaled the start of the collapse of the 'bubble', since the rise in interest rates deflated the value of assets such as land, real estate and stocks. The sudden drops in the collateral value of loans caused severe problems for the Japanese banking 
industry (Hamada 1995). As a direct consequence of the decreased value of loan collaterals banks became encumbered with NPLs and problems to meet bank capital adequacy ratios. The problems within the Japanese banking sector were also reflected by the continuing decline in their lending activities. The domestic demand for loans used to be fulfilled mainly by foreign banks, highlighting the problematic supply of loans by domestic banks (Van Rixtel, 2002).

The initial general policy response to the crisis came in June 1996 by monetary authorities that passed six financial reform laws, to solve the bad loan situation and related collateral problems. Thereafter, the end of 1996 was characterized by the implementation of reform legislation, which aimed at the bailout of the collapsed housing loan companies and the strengthening of the Deposit Insurance Corporation. In June 1997, the Diet approved a new Bank of Japan Law that considerably increased the independence of the Japanese central bank. At the end of the same year, a number of major financial institutions collapsed, which could be interpreted as the end of the 'toobig-to-fail' policy. The establishment of a new supervisory authority, the Financial Supervisory Agency (FSA) and the announcement by the MoF of a considerable decrease in the number of its informal circulars happened between June and October 1998. According to FSA inspections conducted in collaboration with the BoJ, the second-tier regional banks had significantly understated the amount of their problem loan.

In October 1998 the establishment of the Financial Reconstruction Commission (FRC) contributed significantly to the suppression of the Crisis. In relation to the FSA's inspection results of regional banks, the FRC decided to inject $¥ 260$ billion into three regional banks (Ashikaga Bank, Hokuriku Bank and Bank of the Ryukyus) and one second -tier regional bank (Hiroshima-Sogo Bank). Several banks were recapitalized using private money from their 'main banks', including Kanto Bank and Chiba Kogyo Bank, while in July 2000 further consolidation of bank supervision was attained by integrating the FSA and MoF's Financial System Planning Bureau into the Financial Services Agency (FSEA).

In 2000, the supervisory authorities continued to inject public funds into the banking system. A total of $¥ 170$ billion in financial assistance was provided to four regional banks. Japanese short-term interest rates close to zero-lower bound and weak economic activity plagued by significant deflation risks led Bank of Japan (BoJ) to adopt the first round of an unconventional monetary policy strategy known as 
quantitative easing $(\mathrm{QE})$. The first $\mathrm{QE}$ program by BoJ constitutes an increase in the commercial bank current account balance (CAB) from $¥ 5$ trillion to $¥ 35$ trillion over a four-year period, known as a QE 1 program, starting in March 2001 and ending in 2005 (Watanabe, \& Yabu, 2013).

The second wave of the turbulence came in 2008 when the USA and other advanced economies faced the collapse of the financial markets and the consequent credit crunch. This occurred when the Japanese economy was still in the process of stabilization. Even though BoJ claimed that the first QE did not meet expectations, BoJ launched the second round of QE on 4 August 2011. BoJ increased the commercial bank current account balance from $¥ 40$ trillion to a total of $¥ 50$ trillion. BoJ then further expanded its asset purchase program in October 2011, by $¥ 5$ trillion to a total of $¥ 55$ trillion, and from $¥ 60$ to $¥ 70$ trillion a year on April 2013, and $¥ 80$ trillion of bonds purchases a year on 31 October 2014. This latter QE program was accompanied by other government expansion measures and has been characterized in recent literature as an "Abenomics" period (De Michelis and Iacoviello, 2016), which is in contrast with the situation in the 1990s where the MoF was unwilling to boost public spending given its concern for the budgetary situation. Accordingly, the BoJ had to provide economic stimulation (Okina et al., 2000).

\section{Literature Review}

\subsection{Bank Lending channel: Origin and the Direction of Contemporary Research}

Over the last three decades, there have been a number of the theoretical and empirical studies that attempt to explain how monetary policy is transmitted to the real economy. The most influential papers in these debates include King (1986) and Bernanke and Blinder (1988) that initiated a rigorous discussion on this topic. The prevalent credit view literature then examines a bank lending channel (BLC) under the conventional monetary instruments. They show that monetary policy shocks lead to the shift of banks' loan supply schedules. When the central bank tightens its monetary policy and squeezes liquidity from the financial system, banks have to restructure their assets and reduce their reservable funds to nonreservable funds.

Kashyap and Stein (2000) show that irreversible funds are affected by adverse selection problems and credit rationing. That means banks lose available funds for 
underwriting new loans, which is reflected in the credit contraction to their bankdependent clients. Empirical research on BLC under the assumption of conventional monetary policy is extensive. These studies include Kishan and Opiela, (2000, 2006), Gambacorta and Marques-Ibanez, (2011), Olivero et al. (2011) among others. Another recent strand of the literature reflects on the low-interest-rate environment that leads banks to undertake risks affecting the efficient operation of the bank lending channel (Borio and Zhou, 2012; Altunbas et al., 2012; Delis et al., 2017).

The use of the non-conventional monetary instrument - Quantitative Easing by central bankers during the Global Financial Crisis (GFC) opens a new discussion on monetary policy effectiveness. In particular, how QE policy is transmitted to the real economy. Güntner (2015) introduces bank liquidity risk into a business cycle model. It is argued that asset purchases could prove ineffective because commercial banks form a large capital base and hold less liquidity. Likewise, Di Maggio and Kacperczyk (2017) claim that non-standard US monetary policies at the zero-lower bound (ZLB) created an adverse shock to the competitiveness of a significant part of the shadow banking system. That triggered lower capital supply to the financial and large corporate sectors and increased the financial market's exposure to runs and defaults.

In the case of the UK, Butt et al. (2014) argue that UK QE leads to "flighty" deposits in banks and thus diminishes the traditional bank lending channel. Joyce and Spaltro (2014) show that UK QE1 led to small but a statistically significant upward movement in bank lending growth, which was more effective within the segment of the small- and medium-sized banks. Low capitalization is found to impede the QE impact on bank lending. Churm et al. (2015) find that the UK Funding for Lending Scheme (FLS) reduces bank funding costs and increases incentives to lend.

Similarly, Carpenter et al. (2014) provide evidence that unconventional actions taken in the US and the Euro area reduced bank funding volatility and that consequently led to the increased loan supply. The positive effect of US QE across the globe is found by Anaya et al. (2017) who report lower lending rates in EMEs, while Barroso et al. (2016) find a significant credit growth in Brazil.

In the European context, Casiraghi et al. (2013) support the ECB's unconventional practices and show that these practices led to higher credit supply in Italy. Darracq-Paries and De Santis (2015) argue that the ECB's 3-year Long Term Refinancing Operations (LTROs) resulted in lower lending rate spreads. Similarly, Garcia-Posada and Marchetti (2016) find that the Very Long Term Refinancing 
Operations (VLTROs) by the ECB had a modest positive effect on bank credit supply to firms in Spain, driven by credit to small- and medium-sized enterprises. Furthermore, this impact was larger for illiquid banks.

\subsection{Evidence for bank lending channel under unconventional policies in Japan}

In this subsection, we provide a summary and the identification of the gap of current research on QE in Japan. Japan was the first country that adopted the use of unconventional monetary policy. Since its introduction in 2001, a number of research studies were published on this topic. Kimura et al. (2003) and Ugai (2007) used aggregate macroeconomic data and failed to support any significant change in bank balance sheets during this first QE program. Shirakawa (2002) argues that a marginal effect of QE in Japan was caused by the fact that Japanese banks had a preference of holding liquidity because of the poor economic performance of the corporate sector and the Japanese economy as a whole. Hosono (2006) supports this result by showing that Japanese banks with stronger liquidity positions had lent more than those banks with less liquidity before the QE was adopted. Kobayashi et al. (2006) then find that increases in current account balances appeared to have benefited weaker banks with a higher bad-loan ratio, but they do not find a significant relationship between bank stock returns and liquidity position.

Bowman et al. (2015) use bank-level data over the first period of QE. In their regression analysis, they find a positive response of lending to liquidity positions during the first year of the program. Nevertheless, the effect is small as interbank lending declined and it is more intense for weaker banks. Wang (2016) compares QE effects between Japan and the US, and finds that the positive effects on lending by large banks are more pronounced in the US.

\subsection{Weak evidence for other QE channels in Japan}

It is also necessary to highlight two major unconventional channels of monetary policy apart from BLC, which comprise the portfolio rebalancing and the signaling channel as discussed by Bernanke and Reinhart (2004). As for the portfolio rebalancing channel, BoJ purchased a large volume of long-term government bonds every month to reduce 
long-term rates. ${ }^{2}$ That forced banks to rebalance their portfolios and boost economic activity. Oda and Ueda (2005) do not provide evidence for this type of unconventional channel in Japan due to fairly weak purchases. The signaling channel is broadly seen as a commitment of a central bank to yield curve control until the real economy rebounds (Eggertsson and Woodford, 2004; Krishnamurthy and Vissing-Jorgensen, 2011). In the Japanese case, there is no anecdotal evidence as such (Okina and Shiratsuka, 2004; Baba et al., 2006). Similar results are found on signaling or portfolio balance effects in Japan by Bauer \& Neely (2014) when studying the international effect of US unconventional policy.

\subsection{Evidence for QE effects on Japanese economic activity by using VAR models}

Recent studies that deploy Vector Autoregressive models (VAR) identify economic activity responses to unconventional monetary policy measures in Japan. Girardin and Moussa (2011) in a Markov-switching VAR show that quantitative easing prevented a further recession and deflation but also provided considerable stimulation to both output and prices. However, such a policy has to be accompanied by a healthy and strong financial system. Schenkelberg and Watzka (2013) apply a sign restriction structural VAR (SVAR) and show that the Japanese quantitative easing experiment was successful in temporarily stimulating real activity, but it did not lead to a persistent increase in inflation. Matsuki et al. (2015) provide further evidence that quantitative easing in Japan increases inflation rates, while qualitative easing spurs economic activity. Hanisch (2017) points out that the effectiveness of expansionary monetary policy differs with respect to the policy instruments used. A shock that decreases the short-term interest rate has a strong positive effect on output and a modest effect on prices. A monetary policy shock that expands the monetary base has a positive, but weak and somewhat transitory, effect on output, and a strong effect on goods and stock prices. Michaelis and Watzka (2017) use a time-varying parameter vector autoregression (TVP-VAR) model with a new set of sign restrictions to compare the effectiveness of QE policies over time on GDP and CPI in Japan. They find a more pronounced effect over the 'Abenomics' period compared to earlier QE periods. Gambacorta et al. (2014) by using a panel VAR framework find that a QE shock leads

\footnotetext{
${ }^{2} \mathrm{BoJ}$ used the same policy also in 2017 as a reaction to market turbulences.
} 
to temporarily higher economic activity and consumer prices, with no differences in impacts across eight advanced economies including Japan.

\section{Data and Methodology}

\subsection{Data - Demand vs supply driven loan growth}

In order to investigate a possible active bank lending channel in Japan, semi-annual data for 104 Regional I and Regional II banks have been collected from the Japanese Bank Association over the period from 2000 to 2015 . We use the balanced panel data set that is combined in a panel VAR model with GDP, inflation, implied volatility index and central bank's current account balance growth that is as an indicator of the enlargement of the BoJ balance sheet due to QE policy, as in Bowman et al., (2015). This account refers to banks' liquid assets as the sum of vault cash, and deposits at the BOJ, thus indicating the liquidity provided by BoJ to banks. Regional banks in Japan are divided into two groups: Regional Banks I, and the Second Association of Regional Banks (also known as Regional Banks II), even though there are no functional differences between the two types. Henceforth we shall call them regional banks. Both groups of banks underwent several recapitalization programmes that had been introduced by the Government in order to stabilize the system and restore lending activities. Despite those activities, regional banks have been facing severe problems with their performance (Fukuyama and Weber, 2008; 2015; Assaf et al., 2011). So far regional banks' activities have been restricted due to the lack of capital and accumulated NPLs.

We construct accounting ratios for different bank assets and liabilities categories. The ratio of Liquid Assets/Total Assets includes cash, due-from-banks and call loans and provides information about the level of liquidity a bank holds, while the ratio of Securities/Total Assets provides insights about the securities holdings preferences of the bank. Deposit growth (Deposit_Growth) and capital adequacy (Equity/Total Assets) can be very informative concerning the ability of the bank to provide loans. The inverse of the latter ratio is also known as equity multiplier indicating the leverage of the bank. 
Special attention is paid to the loan growth of regional banks that can add significantly to real economic activity given their lending specialization on small- and medium-sized firms (Fukuyama \& Matousek, 2017).

Figure 1a,b provide information on changes in current account balances as percentage of total assets by the BoJ along with the time evolution of the GDP index in logarithmic levels (1a) and inflation (1b). The BoJ conducted two QE programs. The first program captures the period from 2002 to 2005 and the second one captures the recent period accompanied by a series of easing fiscal measures (Abenomics period). What is interesting is the positive correlation with some time lag that seems to exist in some degree between QE and GDP or inflation. However, questions about the efficiency of the first QE program led to a more holistic easing economic policy over the last years. However, we have to mention that the absence of a QE program might lead the economy into more difficulties not easily seen in the current graph (Blot et al., 2016) $)^{3}$.

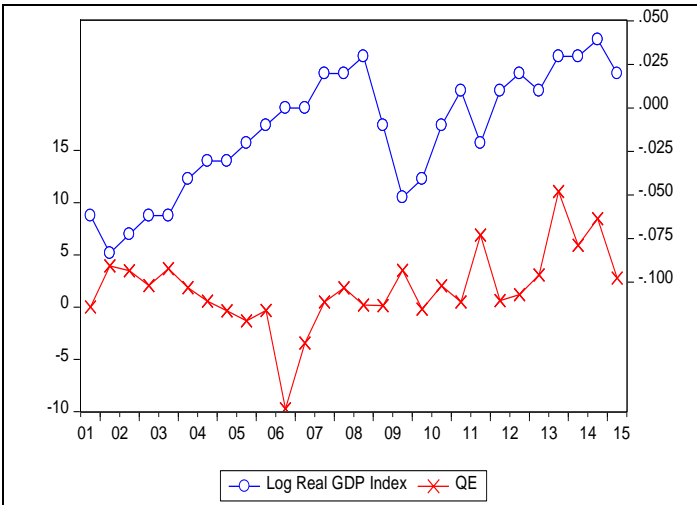

Fig. 1a. GDP vs. changes in central bank reserves/assets

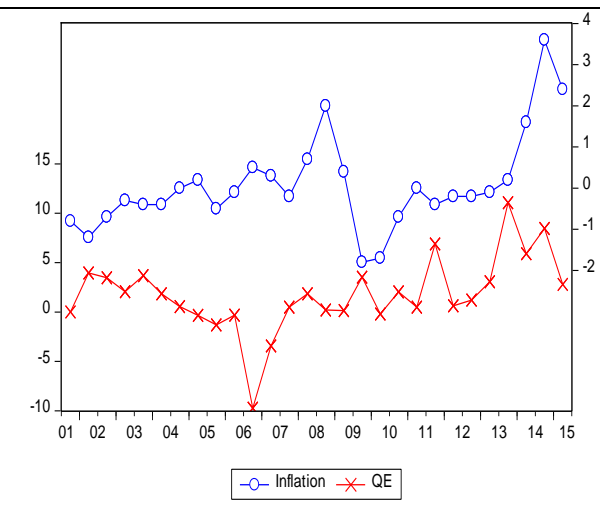

Fig. 1b. Inflation vs. changes in central bank reserves/assets

Note: QE indicator shows the central bank's current account balance growth throughout the study, and it is used as an indicator of the enlargement of the BoJ balance sheet due to QE policy

In order to decompose loan growth into demand and supply driven, we refer to several studies (Tobin, 1970; Bernanke and Blinder, 1988) by assuming the existence of a competitive equilibrium which is characterized by equality among aggregated supply and demand loan curves with a nominal rate which clears the market. ${ }^{4}$ More recently, Ramos-Tallada (2015) also assumes the existence of a competitive

\footnotetext{
${ }^{3}$ http://www.europarl.europa.eu/RegData/etudes/IDAN/2016/578994/IPOL_IDA(2016)578994_EN.pdf ${ }^{4}$ However, in contrast to Bernanke and Blinder (1988) which are not assuming the existence of credit rationing, Stiglitz and Weiss (1981) provide a model in which aggregate demand and supply loan curves do not intersect and credit rationing exists.
} 
equilibrium point among supply and demand loan curves and decomposes loans into demand and supply driven. Specifically, in Figure 1c, we can observe a clearing market for loans where a loan supply function (LS) that is positively related to the lending rate $\left(r_{L}\right)$ and a loan demand function (LD) that is negatively related to $r_{L}$. Then the initial equilibrium price and quantity of loans are given by the intersection of demand and supply for loans at point A. The interest revenues from loans in the second half of the fiscal year over the amount of total outstanding gross loans during the first half can be used as a proxy for the lending rate for each bank. Then first differences of this variable are calculated in order to proxy lending rate changes $\left(\Delta r_{L}\right)$.

When a positive loan growth $(\Delta \mathrm{L})$ occurs with a positive increase in lending rate changes $\left(\Delta r_{L}\right)$, then this loan growth may be attributed to the demand-driven loan shift as can be seen in Figure 1b (movement from A to C, or movement of LD to LD'). Otherwise, when positive loan growth coexists with a negative change in the price of loans, then this positive growth in the amount of loans may be attributed to a supplydriven shift (movement from A to B or movement of LS to LS'). Therefore, by using a dummy variable, the loan growth has been decomposed into supply- (Loan_Growth_S) and demand-driven loan growth (Loan_Growth_D), depending on whether loan changes times lending rate changes equals a positive or a negative number.

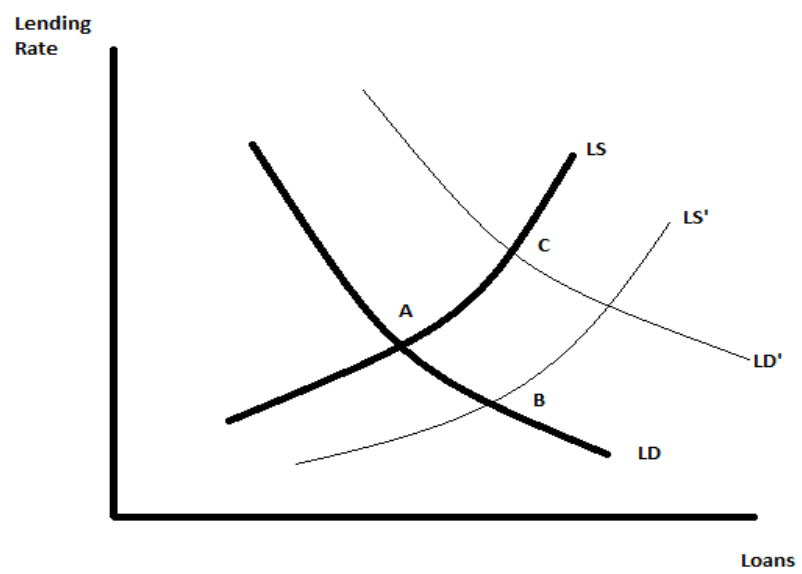

Fig. 1c. Supply versus demand- driven loan growth. Note: LS indicates the loan supply curve, while LD is the loan demand curve. Point $\mathrm{A}$ is the initial equilibrium point, while points $\mathrm{B}$ and $\mathrm{C}$ are new equilibrium points achieved after supply- and demand- driven factors, respectively.

Table 1 presents mean and standard deviation for the whole sample of regional banks as well as for the two sub-samples based on the size and the level of NPLs. The criterion of dividing banks into two subgroups is the median of asset size and the median of NPLs. We observe from Table 1 that the loan growth can be mainly attributed 
to supply-driven rather than demand-driven forces. Large banks, as expected, have on average higher growth rates for loans and deposits, and securities holdings compared to smaller banks. Smaller banks although having similar Equity/Assets ratios, and maintaining higher levels of liquid assets, show higher levels of NPLs.

Table 1 Descriptive Statistics for Assets and Liabilities elements

\begin{tabular}{|c|c|c|c|c|c|c|c|c|c|c|}
\hline \multirow[b]{2}{*}{ Variable } & \multicolumn{2}{|c|}{ Whole Sample } & \multicolumn{2}{|c|}{ Large Size } & \multicolumn{2}{|c|}{ Small Size } & \multicolumn{2}{|c|}{ High values of NPLs } & \multicolumn{2}{|c|}{ Low values of NPLs } \\
\hline & Mean & Std. Dev. & Mean & Std. Dev. & Mean & Std. Dev. & Mean & Std. Dev. & Mean & Std. Dev. \\
\hline Loan_Growth & 0.76 & 5.88 & 0.98 & 6.15 & 0.55 & 5.58 & 0.31 & 6.57 & 1.19 & 5.11 \\
\hline Loan_Growth_D & 0.02 & 5.66 & 0.11 & 5.97 & -0.08 & 5.32 & -0.05 & 6.39 & 0.08 & 4.86 \\
\hline Loan_Growth_S & 0.75 & 1.61 & 0.87 & 1.55 & 0.62 & 1.65 & 0.36 & 1.49 & 1.11 & 1.63 \\
\hline Deposit_Growth & 1.02 & 3.53 & 1.17 & 3.63 & 0.86 & 3.42 & 0.63 & 4.11 & 1.38 & 2.83 \\
\hline $\begin{array}{l}\text { Liquid } \\
\text { Assets/TA }\end{array}$ & 6.05 & 3.02 & 5.45 & 2.85 & 6.66 & 3.07 & 6.38 & 2.74 & 5.74 & 3.24 \\
\hline Securities/TA & 24.34 & 7.44 & 27.18 & 7.54 & 21.48 & 6.13 & 21.79 & 6.27 & 26.77 & 7.65 \\
\hline Deposits/TA & 89.51 & 3.80 & 87.57 & 3.81 & 91.47 & 2.61 & 90.71 & 3.27 & 88.37 & 3.93 \\
\hline Equity/TA & 4.49 & 1.07 & 4.64 & 1.10 & 4.34 & 1.01 & 4.42 & 1.11 & 4.56 & 1.02 \\
\hline NPLs/TA & 3.39 & 1.93 & 2.80 & 1.51 & 3.99 & 2.11 & 4.83 & 1.83 & 2.02 & 0.45 \\
\hline TA & $2,777,416$ & $2,285,706$ & $4,417,695$ & $2,159,398$ & $1,121,777$ & 578,068 & $2,069,121$ & $1,794,613$ & $3,449,861$ & $2,490,200$ \\
\hline
\end{tabular}

Notes: By dividing the whole sample into two groups based on the mean values of total assets and NPLs we calculate descriptive statistics for variables of interest in each sub-sample

When we analyze the subgroups of banks based on variations in NPLs interesting findings arise. More specifically, banks with low levels of NPLs indicate on average higher growth rates for loans and deposits and do keep more securities holdings. These findings cause our empirical investigation to be established via the following two steps. Firstly, we estimate our basic VAR model and then we re-estimate our model for two different subgroups based on the size and risk measure of NPLs, in order to identify any heterogeneity among our findings.

\subsection{Model setup}

\subsubsection{The Conventional Single equation approach}

The conventional model adopted by the literature for testing the bank lending channel uses a single-equation general form in a panel data context (see for instance Gambacorta, 2003; Altunbas et al. 2010; Ramos-Tallada, 2015; Bowman et al., 2015). The dynamic model with compounded coefficients is specified in equation (1): 
$\Delta \log L_{i, t+j}=C+\beta_{i} \Delta \log L_{i, t}+\beta_{s} R_{s, t}+\sum_{k=1}^{K} \beta_{k}\left(R_{s, t} X_{k, i, t}\right)+\sum_{m=1}^{M} \beta_{m}\left(X_{m, i, t}\right)+$

$e_{i, t+j} \quad i=1, \ldots, N \quad t=1, \ldots, T \quad e_{i, t+j} \sim \operatorname{iid}\left(0, \sum_{e}\right)$

where $\Delta \log L_{i, t+j}$ is the first difference of logarithmic loans between $t$ and $t+j$ periods, $R_{S, t}$ the policy rate over period $\mathrm{t}$ and $X$ a vector of exogenous precautionary or diversification variables that can affect directly loan growth or indirectly via the lending channel. The total marginal impact of $R_{s, t}$ on $\Delta \log L_{i, t+j}$ is therefore given by the compounded coefficient $\beta_{s}+\sum_{k=1}^{K} \beta_{k} X_{k, i, t}$.

\subsubsection{The Panel VAR proposed Approach}

However, single equation studies identify the main determinants of bank lending without taking into account any feedback effects of lending on other variables and without highlighting the transmission channel of monetary policy on the real economy. Since Sims' (1980) seminal paper, the typical framework to investigate monetary policy transmission mechanisms, including a bank lending channel, is the standard VAR framework ${ }^{5}$

. The main advantage of using a VAR model is that it allows for dynamic interdependencies among all variables that are treated as endogenous. The characteristic presentation of a VAR model in applied macroeconomics has the following form:

$$
V_{t}=B_{0}(t)+B(l) V_{t-1}+A u_{t} \quad u_{t} \sim \operatorname{iid}\left(0, \sum_{u}\right)
$$

Where $V_{t}$ is a $\mathrm{Gx} 1$ vector of endogenous variables and $B(l)$ is a polynomial in the lag operator, while the deterministic components of the data are incorporated into $B_{0}(t) . \quad \mathrm{A}$ is the contemporaneous impact matrix of the mutually uncorrelated disturbances u.

\footnotetext{
${ }^{5}$ Yang and Zhou $(2013,2016)$ have extensively highlighted the advantages of applying structural VAR models investigating both credit risk spill-overs among financial institutions and volatility spill-overs during unconventional monetary policy periods.
} 
The Panel Vector Autoregressive models (PVAR) treat all variables as endogenous and independent, but with the cross-sectional dimension that can be represented as follows:

$v_{i t}=B_{0 i}(t)+B_{i}(l) V_{t-1}+A_{i} u_{i t} \quad i=1, \ldots, N \quad t=1, \ldots, T$

Where $V_{t}$ is a stacked version of $v_{i t}$, the vector of $\mathrm{G}$ variables for each unit $\mathrm{i}$, i.e. $V_{t}=\left(v_{1 t}^{\prime}, \ldots, v_{N t}^{\prime}\right)$, and $u_{i t}=\left[u_{1 t}^{\prime}, u_{2 t}^{\prime}, \ldots, u_{N t}^{\prime}\right]^{\prime} \sim i i d(0, \Sigma)$ is the $G \times 1$ vector of contemporaneously correlated random disturbances with zero mean and the nonsingular variance-covariance matrix $\Sigma . A_{i}$ is the contemporaneous impact matrix of the mutually uncorrelated disturbances $\mathrm{u}_{\mathrm{i}}$ for each bank $\mathrm{i}$.

Canova and Ciccarelli (2013) show that Bayesian panel VARs are particularly suited to analyse the transmission of idiosyncratic shocks across units and time, and to construct average effects across a heterogeneous group of units. Moreover, it may be used to examine the extent of dynamic heterogeneity among endogenous group units.

The use of the PVAR model also allows us to combine variables like GDP, inflation rate, Japanese implied stock market volatility (VIX) and the central bank current account balance $(\mathrm{CAB})$. This captures general economic and monetary conditions with the above-mentioned bank-specific variables and investigates any dynamic interactions among them as in the case of UK banks (Aiyar et al., 2016, Philippas et al., 2019). Banks' dynamic responses to QE shock with short time-series information can be obtained in a PVAR. Among major advantages of this technique is that it accounts for individual bank characteristics at the level of the variables by introducing fixed effects and isolating the response of the bank credit channel to macroeconomic shocks, while allowing for unobserved bank heterogeneity (Frame et $a l .$, 2012; Love \& Turk-Ariss, 2014).

A general reduced form of our main estimated model is presented below by treating all variables as endogenous and allowing time lags across variables. In other words, a first order Panel Vector Autoregressive $\left(\mathrm{PVAR}^{6}\right)$ model of the following form is estimated:

\footnotetext{
${ }^{6}$ Our type of the panel vector autoregression model (PVAR) was initially developed by Love and Zicchino (2006) to investigate the linkage between credit risk and various bank-levels and macroeconomic correlates.
} 
$v_{i t}=\Gamma_{0}+\Gamma_{1} v_{i, t-1}+f_{i}+p_{t}+A_{i} u_{i t} \quad i=1, \ldots, N \quad t=1, \ldots, T$

where $v_{i t}$ is a nine-variable vector \{GDP in logarithmic level, inflation, VIX, QE, Loan_Growth_S, Loan_Growth_D, Liquid/TA, Deposit_Growth, Equity/TA\}.

GDP and inflation are the two critical measures of economic performance that usually focus on central bank; implied volatility index (VIX) is well known in the financial literature as a "fear index" and covers any financial turmoil, while QE instead of policy rate is the main monetary policy instrument at zero lower bound of interest rates. The rest variables capture a series of bank management issues concerning liquidity preference versus security holdings, lending, capital and leverage issues.

In our model "individual heterogeneity" is allowed among variables by introducing fixed effects, denoted by $f_{i}$ in equation (4). Additionally, country-specific time dummies $p_{t}$, are added to equation (4) to capture aggregate, global shocks that may affect all banks in the same way.

Since the panel VAR model is estimated, impulse response analysis is applied. In this type of analysis, the isolated random shock to each variable is identified by a mixture of zero and sign restrictions as in Eickmeier and Hofmann, (2013); Gambacorta et al., (2014); Hanisch (2017); Schenkelberg and Watzka (2013). Confidence intervals are generated using Monte Carlo simulations. More specifically, we assume that there is only a lagged impact of QE shock on GDP and inflation, or simply the contemporaneous impact of $\mathrm{QE}$ on both variables is restricted to be zero. Innovations on GDP, inflation, stock market implied volatility and rest bank variables are allowed to have an immediate effect on BoJ balance sheet. Moreover, we assume that unconventional policy reduces implied stock market volatility, although the QE may immediately respond to VIX. By incorporating a risk/volatility index in the PVAR and by conditioning the QE shock on this indicator, we can disentangle exogenous innovations to the central bank balance sheets from endogenous responses to financial market risk. At this point, we have to mention also that identify the shock recursively, i.e. by the Cholesky decomposition where the individual banks' balance sheets variables ordered last, implies that the macroeconomic variables do not react contemporaneously to shocks to the individual banks' variables (Kilian \& Lütkepohl, 
2017). Thus, the identifying assumptions in our paper as in Gambacorta et al., 2014 are summarized in Table $2^{7}$ :

Table 2 Identification of An Unconventional Monetary policy Shock

\begin{tabular}{|c|c|c|c|}
\hline Output & Prices & VIX & Central Bank Assets \\
\hline \hline 0 & 0 & $\leq 0$ & $>0$ \\
\hline
\end{tabular}

In our model, let $v^{t}$ be the history for $v_{t}, \varphi^{t}$ the trajectory for the coefficients up to $t, \Omega^{t}$ the trajectory for the variance coefficients up to $t$. Then by letting:

$v_{t+1}^{t+\tau}=\left[v_{t+1}^{\prime}, \ldots, v_{t+\tau}^{\prime}\right]^{\prime}$ to be a collection of future observations

$\varphi_{t+1}^{t+\tau}=\left[\varphi_{t+1}^{\prime}, \ldots, \varphi_{t+\tau}^{\prime}\right]^{\prime}$ to be a collection of future trajectories for $\varphi_{t}$

$W=\left(\Sigma_{u}, \sigma^{2}\right)$

$\xi_{t}^{\prime}=\left[u_{1, t}^{\prime}\right]$, where $u_{1, t}^{\prime}$ are shocks to the endogenous variables

$\xi_{j, t}^{\delta}$ to be a realization of $\xi_{j, t}$ of size $\delta$

and $F_{t}^{1}, F_{t}^{2}$ two conditioning sets as follows:

$F_{t}^{1}=\left\{v^{t}, \varphi^{t}, \Omega^{t}, J_{t}, W, \xi_{j, t}^{\delta}, \xi_{-j, t}, \xi_{t+1}^{t+\tau}\right\}$

$F_{t}^{2}=\left\{v^{t}, \varphi^{t}, \Omega^{t}, J_{t}, W, \xi_{t}, \xi_{t+1}^{t+\tau}\right\}$

Where $\xi_{-j, t}$ indicates all shocks excluding the one in the $\mathrm{j}$-th component, and $J_{t}$ satisfies the following condition $J_{t} J_{t}^{\prime}=\Sigma_{u}$. Then equation (5) produces the traditional impulse response function at horizon $\tau$ to a $\theta$ impulse in $\xi_{j, t}, \mathrm{j}=1, \ldots \mathrm{k}$ :

$$
I R_{v}^{j}(t, \tau)=E\left(v_{t+\tau} \mid F_{t}^{1}\right)-E\left(v_{t+\tau} \mid F_{t}^{2}\right), \tau=1,2, . ., 10
$$

Next, we divide our sample into sub-samples based on the size of banks and their level of NPLs as a measure of risk. That allows us some degree of heterogeneity among banks in the impulse response analysis. If we compare responses across the whole sample and subgroups, we may observe key information about our findings in our main model.

\footnotetext{
${ }^{7}$ The estimation of the Bayesian PVAR model is done in the Bear Toolbox implemented by Dieppe, et. al., (2016).
} 
Suppose that we run the model for one group of regional banks with high NPLs, denoted as $d$, from the full-panel sample. Therefore, the restricted vector to be estimated in equation (4) is now specified as:

$$
V_{t}^{*}=\left[\begin{array}{lll}
v^{\prime}{ }_{1, d, t} & \ldots & v^{\prime}{ }_{N, d, t}
\end{array}\right]
$$

where $V_{t}^{*}$ is the $k_{i, d} \times 1$ vector of endogenous variables for unit $i, i=1, \ldots, N$ and $d$ denotes the banks with high values of NPLs holdings examined for the restricted model. By allowing heterogeneous responses between small versus large banks, and between banks with low versus high values of NPLs, further evidence on the GDP, inflation and other bank variables responses to QE shocks will be provided.

\section{Empirical Results}

\subsection{Impulse Response Analysis based on our basic model}

Figure 2 presents the response of all macro/finance variables of interest to a positive QE shock. By restricting the VIX response to be negative and QE response to be positive, to the positive QE shock, we focus on real GDP and inflation responses. In contrast with previous studies (see, for instance, Bowman et al., 2015) indicating a weakly positive response of GDP on QE, our study highlights a significant positive response. The peak of this positive response is achieved after almost three semesters. Moreover, worth mentioning is the positive and statistically significant response of inflation to QE shock, which holds for almost six semesters. This latter highlights the effectiveness of this policy not only on GDP but also on price levels. The enlargement of the BoJ assets accompanied by the significant reduction in implied volatility index allows us to speak about a significant quantitative easing policy. 


\section{Responses of the macro/finance variables to a $\mathrm{QE}$ shock}
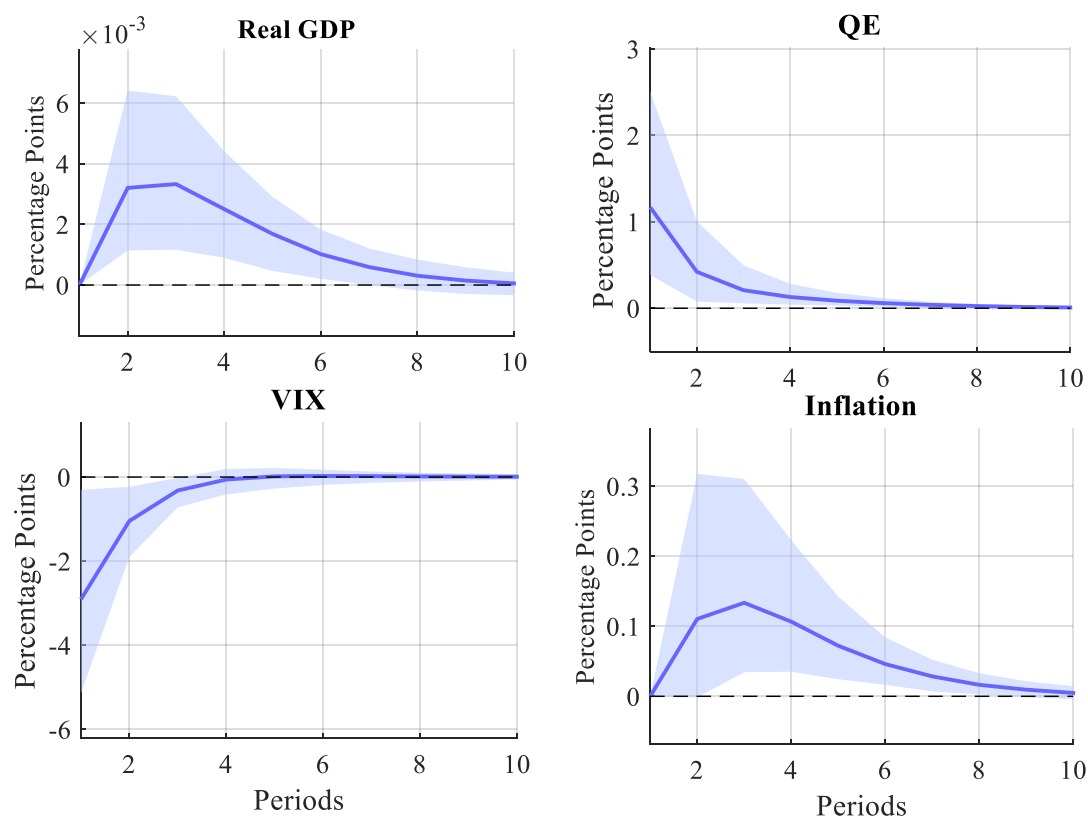

Fig. 2. Responses of the macro/finance variables to a QE shock. The blue line represents the median estimate of the response. The shadow blue area around the median estimate line of the response represents the statistically significant $95 \%$ confidence bands generated from 5000 Monte Carlo bootstrap resampling.

Figure 3 then shows the mean group Panel VAR response of all bank variables of interest to the QE shock. The immediate reduction of the Equity/Assets ratio, which is in line with the previous study by Philippas et al., (2019) for UK banks, implies an increase in leverage that is accompanied by the significant although short-lived increase in the growth rate of loans that are characterized as supply-driven. It is worth mentioning that demand-driven loan growth is reduced, which implies that studies treating the total amount of loans without identifying loan supply in contrast with loan demand may provide wrong signals about the existence of a bank-lending channel. Deposit growth also responds positively but weakly and instantly as part of the money multiplier effects. As far as bank portfolio composition is concerned the liquid assets and the securities expressed as the percentage of total assets increase significantly. What is interesting is that the positive effect on liquidity holdings lasts for almost five periods, while the effect on security holdings holds for almost nine periods. This later result seems to provide evidence for the weak positive response on lending growth and underlines the importance of financial markets in the transmission of this policy to the real economy and prices. Moreover, an increase in security holdings implies an increase in asset prices with significant wealth effects on consumption. 
Responses of the bank variables to a QE shock
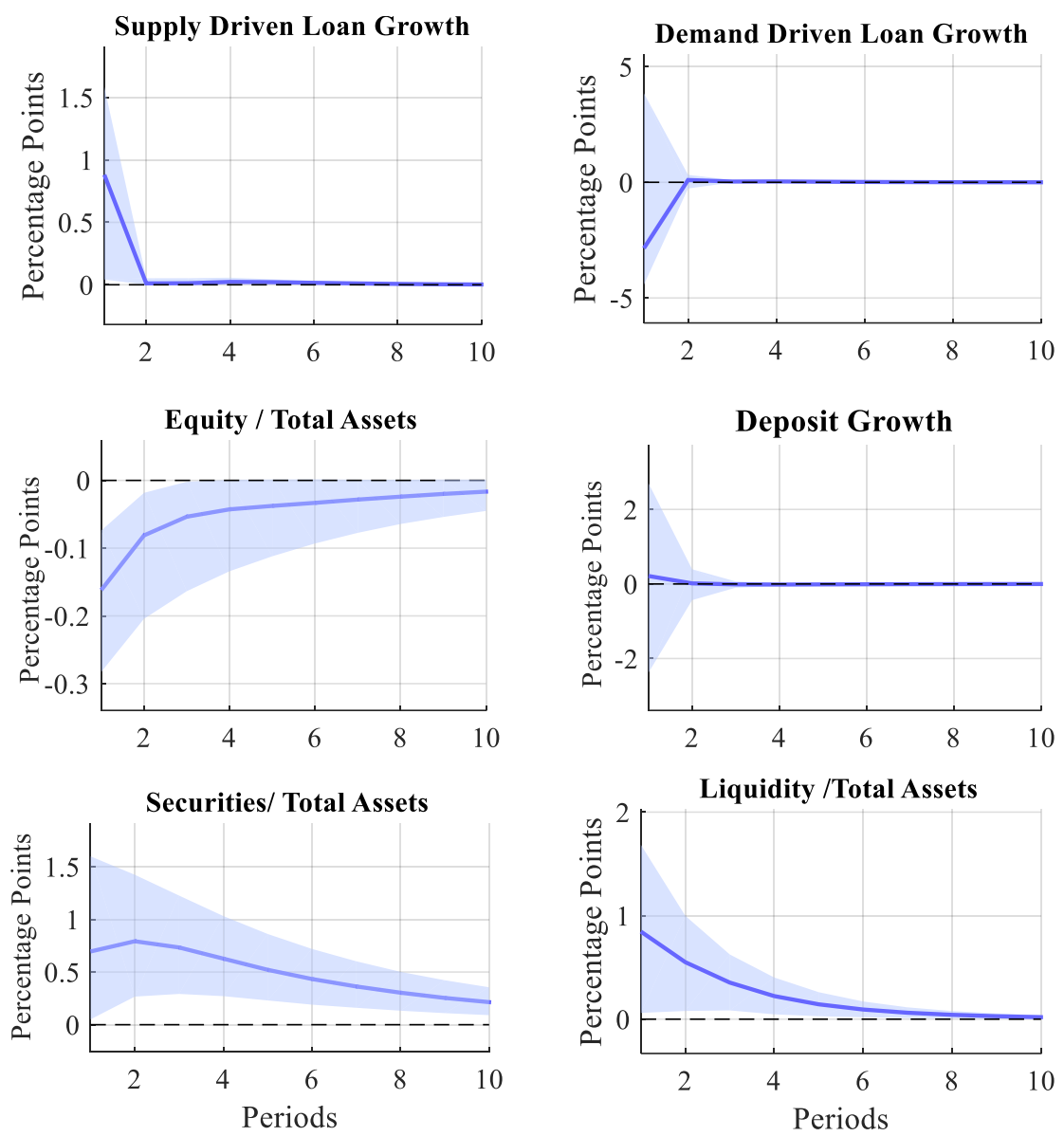

Fig. 3. Responses of the bank variables to a QE shock. The blue line represents the median estimate of the response. The shadow blue area around the median estimate line of the response represents the statistically significant 95\% confidence bands generated from 5000 Monte Carlo bootstrap resampling.

\subsection{Robustness checks allowing for size and NPLs holdings heterogeneity}

In order to investigate further the robustness of our findings, we re-estimate our basic model by allowing firstly heterogeneous responses between small and large banks, and secondly between banks holding low versus high levels of non-performing loans (NPLs).

As can be seen from Figure 4, there is no distinction in the responses of VIX to a positive QE shock when taking into account bank size. However, the positive response of inflation, GDP and security holdings to the QE policy is higher for small- versus large-sized banks, highlighting their importance for the economic activity of Japan. Leverage effects are more prevalent in small- versus large-sized banks when looking at the equity/TA persistent response to $\mathrm{QE}$. 


\section{Responses to QE shock by treating different bank groups based on size}
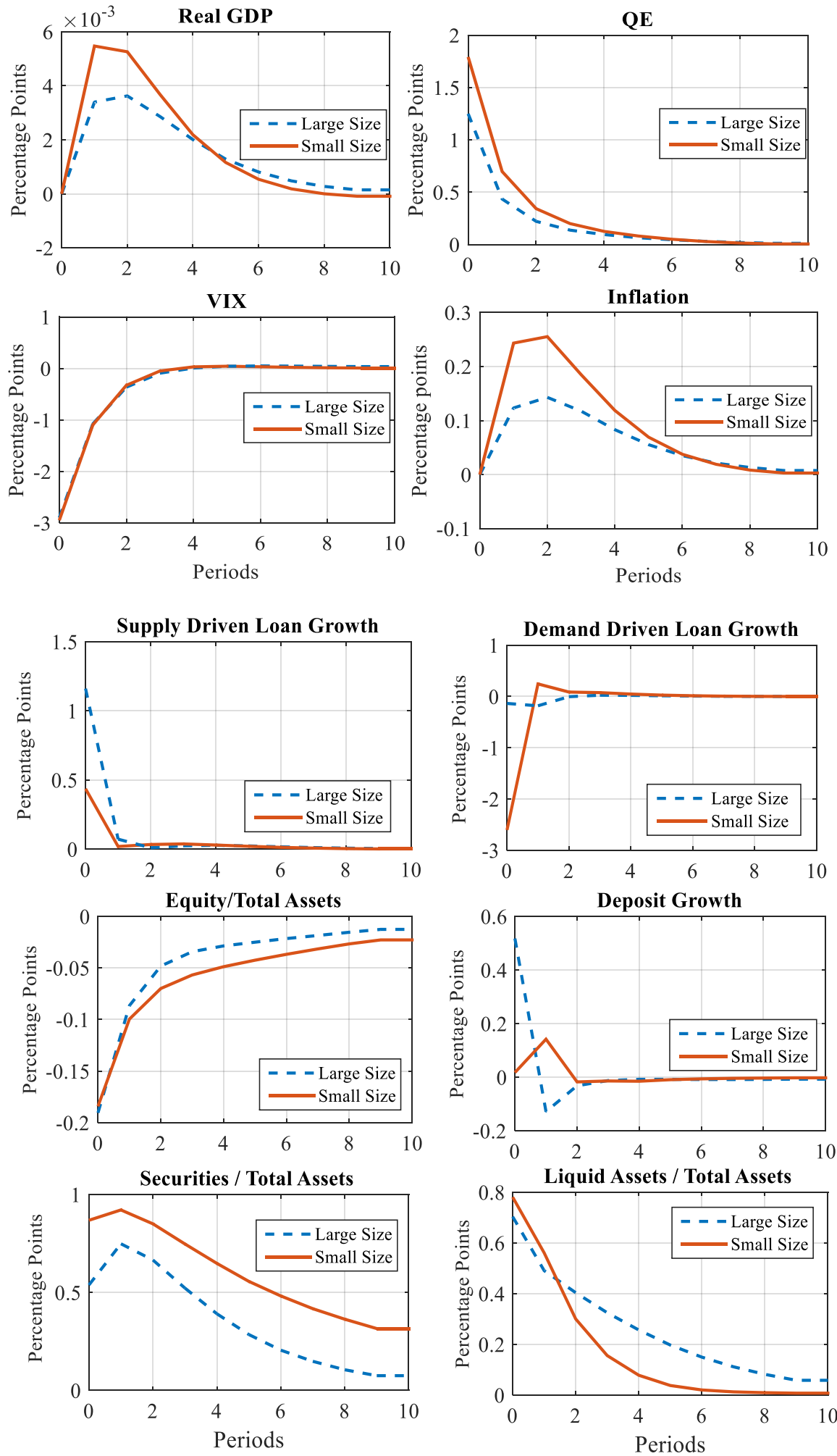

Fig. 4. Responses to QE shock by treating different bank groups based on size. Dotted lines refer to responses by small sized banks, while continuous lines refer to responses by large sized banks. 
Large- in contrast to small-sized banks provide more loans, and in such cases, QE policy presents higher time persistence. Higher deposit growth response for largeversus small-sized banks after a QE shock highlights the higher confidence of deposit clients vis-à-vis large-sized banks. An interesting finding is also the higher time persistence on liquidity holdings for large-sized banks.

By looking on Figure 5, although there is no distinction in responses of liquidity holdings, QE and VIX on QE shocks between banks with high versus low levels of NPLs, there is a slight distinction among supply-driven loans, GDP and inflation responses to QE shock. Banks with high values of NPLs can contribute more on GDP, inflation and supply-driven loans increase due to the QE shock. Time persistence of leverage response to $\mathrm{QE}$ shock is higher for this type of banks. On the opposite, higher deposit growth and reduced demand-driven loans are found after a QE shock on banks with low NPLs holdings. Moreover, banks with high NPLs increase slightly more their security holdings in contrast to banks with low NPLs holdings.

\section{Responses to QE shock by treating different bank groups based on NPLs holdings}
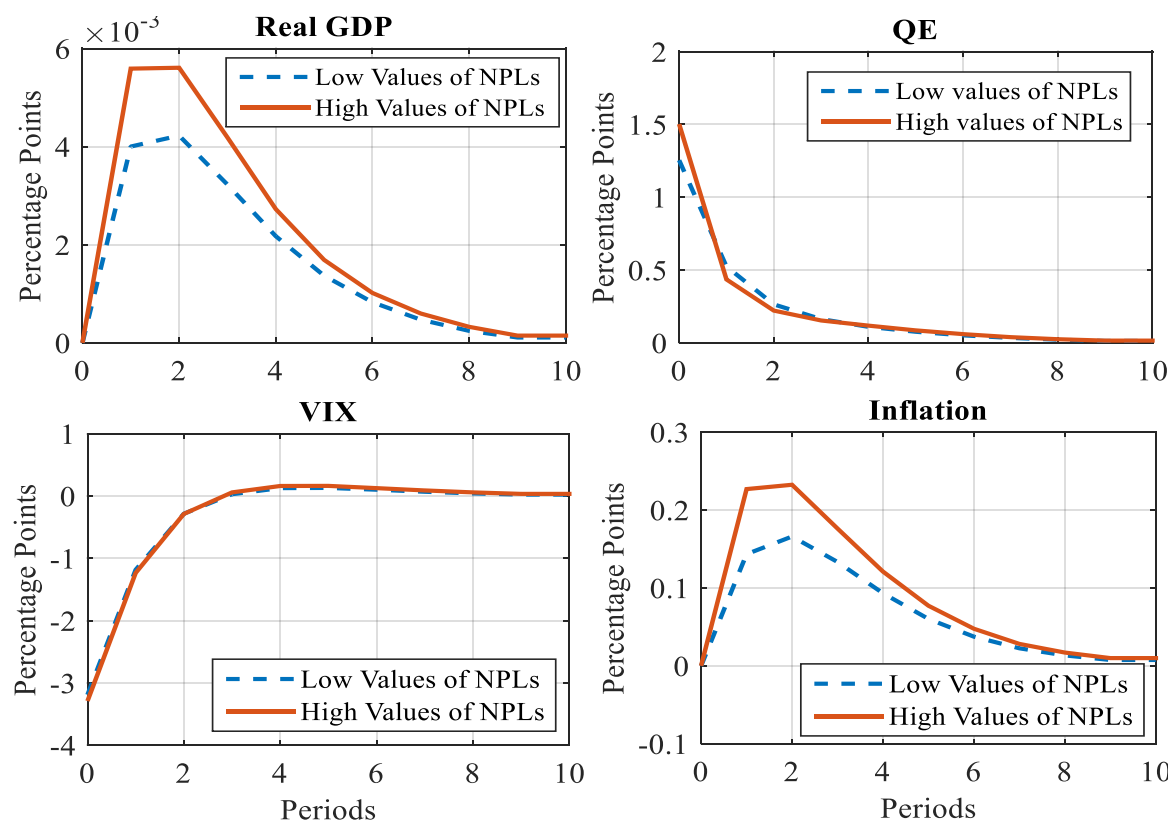

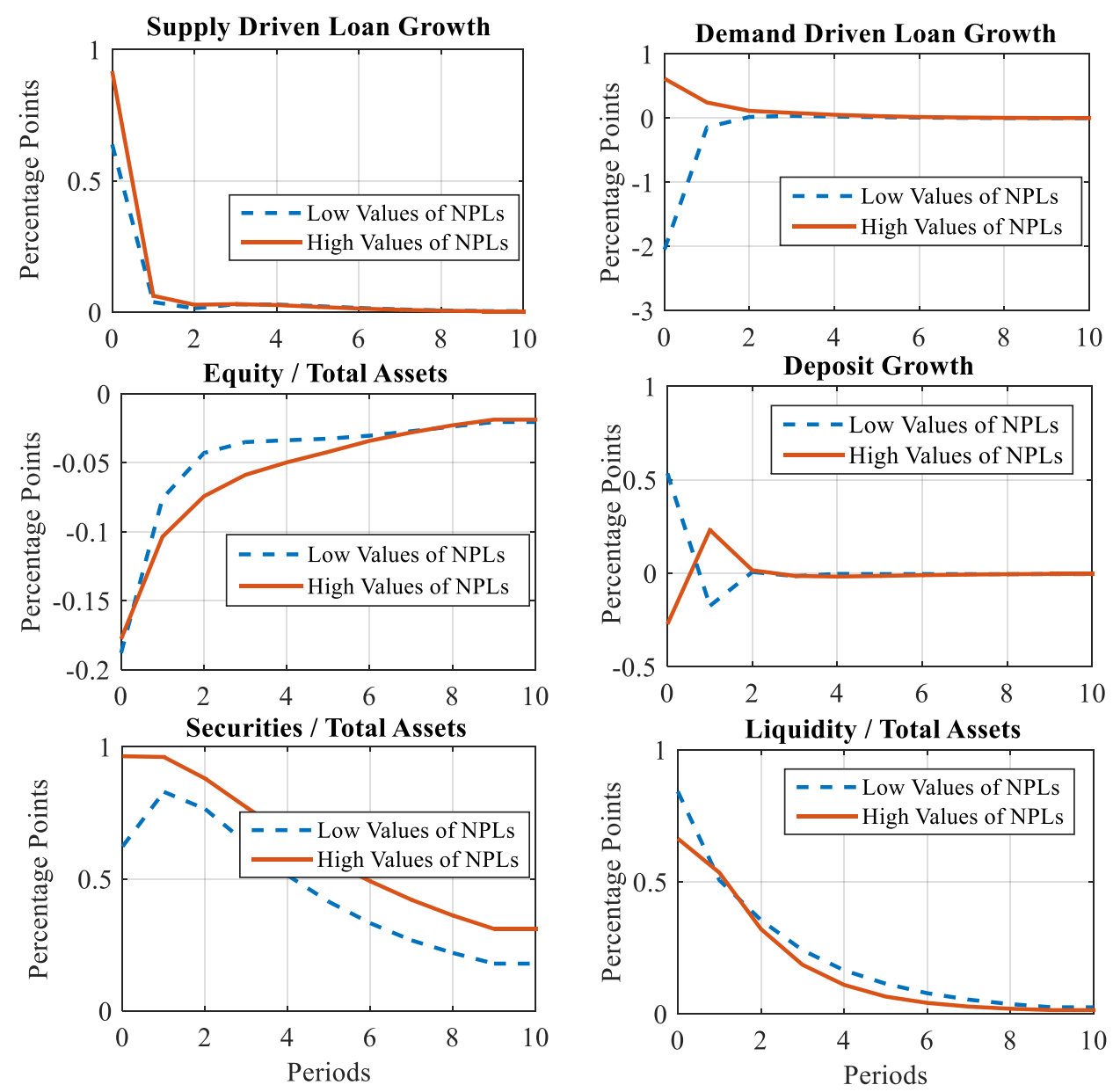

Fig. 5. Responses to QE shock by treating different bank groups based on NPLs holdings. Dotted lines refer to responses by small sized banks, while continuous lines refer to responses by large sized banks.

Summing up, the large-sized banks with high values of NPLs holdings are more responsible for the immediate positive supply-driven loan growth. This type of banks also attracts an increase in deposit growth over quantitative easing policies. While, small-sized banks with high NPLs holdings contribute more to GDP, inflation and security holdings. Moreover, for this type of banks, the immediate drop in the Equity/Asset ratio after an unexpected positive shock to the QE variable, presents higher time persistence, implying higher leverage signals.

\section{Conclusion}

The paper examines the effectiveness of QE conducted by BoJ by analyzing the interaction between BoJ's activities in terms of QE operations and banks' assets and liabilities composition. Based on the analysis we may summarize our results as follows: 
Firstly, we find that the immediate drop of the Equity/Asset ratio due to a positive QE shock implies that the degree of leverage is increased for banks, especially for smallsized banks with high NPLs holdings. Therefore, evidence for the risk-taking channel of monetary policy is provided in line with Borio and Zhou (2012) in the US case. According to this risk-taking channel, a monetary easing environment can help banks to undertake higher risks by increasing their lending activity. Once QE strategies are adopted by BoJ, banks' risk appetite is increasing.

Secondly, GDP, inflation response to QE is positively strong and long-lasting. Small-sized banks with high levels of NPLs holdings contribute more in this direction. Worth mentioning at this point is that the low level of NPLs holdings by large-sized banks is the main driving factor also of the positive deposit growth response to the $\mathrm{QE}$ positive shock.

Thirdly, the increased securities holdings to a monetary easing shock are present in all types of banks, but this effect is higher on small-sized banks with a high level of NPLs holdings. If we combine this latter finding with the result that loan supply is positive although short-lived only for small-sized banks with high NPLs, we can understand their importance in the transmission of QE policies on prices and real activity. In terms of liquid asset responses to a positive QE shock, all banks have an immediate positive preference for liquidity. There should be incentives for banks by monetary authorities to use this liquidity for lending.

Moreover, the main implication of these findings is that monetary authorities should not be very restrictive on policies about capital requirements by small-sized banks with high values of NPLs holdings since this type of banks has beneficial effects on lending and the effectiveness of the QE policy transmission to prices and the real economy.

Additional measures should be implemented by BoJ to transform the extra liquidity kept by banks to loans. Therefore, monetary authorities should pay particular attention to policies for large-sized banks with a low level of NPLs, to help them improve their lending supply. Moreover, policies force banks to hold fewer securities and provide more loans, which can contribute to prices and higher GDP growth since the preference holding of a significant amount of securities deprives the real economy of these funds.

Finally, we have to mention at this point that using the balance sheet as the QE policy instrument can be restrictive. The central bank's balance sheet reflects the 
implementation of QE. However, like many other studies document, the announcement of QE can also have a strong impact on the economy. Therefore, future research should be focused on other aspects of unconventional monetary policy, such as forward guidance and other measures of economic activity like economic sentiment indicators.

\section{Acknowledgements}

We would like to thank Kasper Roszbach (Associate Editor) and the reviewers of the journal for the useful comments raised to our manuscript. Any remaining errors are solely the authors' responsibility.

\section{References}

Aiyar, S., Calomiris, C. W., \& Wieladek, T. (2016). How does credit supply respond to monetary policy and bank minimum capital requirements? European Economic Review, 82, 142-165.

Altunbas, Y., Gambacorta, L., \& Marques-Ibanez, D., (2010). Bank risk and monetary policy. Journal Financial Stability, 6 (3), 121-129.

Altunbas, Y., Gambacorta, L., \& Marques-Ibanez, D. (2012). Do bank characteristics influence the effect of monetary policy on bank risk? Economics Letters, 117(1), 220222.

Anaya, P., Hachula, M., \& Offermanns, C. J. (2017). Spillovers of US unconventional monetary policy to emerging markets: The role of capital flows. Journal of International Money and Finance, 73, 275-295.

Assaf, A. G., Barros, C. P., \& Matousek, R. (2011). Productivity and efficiency analysis of Shinkin banks: Evidence from bootstrap and Bayesian approaches. Journal of Banking \& Finance, 35(2), 331-342.

Baba, N., Nakashima, M., Shigemi, Y., \& Ueda, K. (2006). The Bank of Japan's monetary policy and bank risk premiums in the money market. International Journal of Central Banking, 2(1).

Barroso, J. B. R., da Silva, L. A. P., \& Sales, A. S. (2016). Quantitative easing and related capital flows into Brazil: measuring its effects and transmission channels through a rigorous counterfactual evaluation. Journal of International Money and Finance, 67, 102-122.

Bauer, M. D., \& Neely, C. J. (2014). International channels of the Fed's unconventional monetary policy. Journal of International Money and Finance, 44, 24-46.

Bernanke, B. S., \& Blinder, A. S. (1988). Credit, money, and aggregate demand. The American Economic Review, 78(2), 435-39.

Bernanke, B. S., \& Reinhart, V. R. (2004). Conducting monetary policy at very low short-term interest rates. The American Economic Review, 94(2), 85-90. 
Blot, C., Creel, J., Hubert, P., \& Labondance, F. (2016). The impact of ECB policies on euro area investment: In Policy Department Economic and Scientific Policy A: Economic and Monetary Affairs, Why has ECB's very accommodative policy not yet triggered a rebound on investments, pp. 7-23.

Borio, C., \& Zhu, H. (2012). Capital regulation, risk-taking and monetary policy: a missing link in the transmission mechanism? Journal of Financial Stability, 8(4), 236251.

Bowman, D., Cai, F., Davies, S., \& Kamin, S. (2015). Quantitative easing and bank lending: Evidence from Japan. Journal of International Money and Finance, 57, 15-30.

Butt, N., Churm, R., McMahon, M., Morotz, A., \& Schanz, J. (2014). QE and the bank lending channel in the UK (No. 511). Bank of England Working Paper.

Canova, F., \& Ciccarelli, M. (2013). Panel vector autoregressive models: A survey In VAR Models in Macroeconomics-New Developments and Applications: Essays in Honor of Christopher A. Sims (pp. 205-246). Emerald Group Publishing Limited.

Carpenter, S., Demiralp, S., \& Eisenschmidt, J. (2014). The effectiveness of nonstandard monetary policy in addressing liquidity risk during the financial crisis: The experiences of the Federal Reserve and the European Central Bank. Journal of Economic Dynamics and Control, 43, 107-129.

Casiraghi, M., Gaiotti, E., Rodano, L., \& Secchi, A. (2013). The impact of unconventional monetary policy on the Italian economy during the sovereign debt crisis (No. 203). Bank of Italy, Economic Research and International Relations Area.

Churm, R., Joyce, M., Kapetanios, G., \& Theodoridis, K. (2015). Unconventional monetary policies and the macroeconomy: the impact of the United Kingdom's QE2 and Funding for Lending Scheme (No. 542). Bank of England.

Darracq-Paries, M., \& De Santis, R. A. (2015). A non-standard monetary policy shock: The ECB's 3-year LTROs and the shift in credit supply. Journal of International Money and Finance, 54, 1-34.

De Michelis, A., \& Iacoviello, M. (2016). Raising an inflation target: The Japanese experience with Abenomics. European Economic Review. 88, 67-87

Delis, M. D., Hasan, I., \& Mylonidis, N. (2017). The risk-taking channel of monetary policy in the US: Evidence from corporate loan data. Journal of Money, Credit and Banking, 49(1), 187-213.

Dieppe, A., van Roye, B. \& Legrand, R., (2016). The BEAR toolbox, Working Paper Series 1934, European Central Bank.

Di Maggio, M., \& Kacperczyk, M. (2017). The unintended consequences of the zero lower bound policy. Journal of Financial Economics, 123(1), 59-80.

Eggertsson, G. B., \& Woodford, M. (2004). Optimal monetary and fiscal policy in a liquidity trap (No. w10840). National Bureau of Economic Research.

Frame, W. S., Hancock, D., \& Passmore, W. (2012). Federal home loan bank advances and commercial bank portfolio composition. Journal of Money, Credit and Banking, 44(4), 661-684.

Fukuyama, H., \& Matousek, R. (2017). Modelling bank performance: A network DEA approach. European Journal of Operational Research, 259(2), 721-732. 
Fukuyama, H., \& Weber, W. L. (2008). Estimating inefficiency, technological change and shadow prices of problem loans for regional banks and Shinkin banks in Japan. The Open Management Journal, 1, 1-11.

Gambacorta, L., (2003). The Italian banking system and monetary policy transmission: evidence from bank-level data. In: Angeloni, I., Kashyap, A., Mojon, B. (Eds.), Monetary Policy Transmission in the Euro Area: a Study by the Eurosystem Monetary Transmission Network. Cambridge University Press, pp. 323-334.

Gambacorta, L., \& Marques-Ibanez, D. (2011). The bank lending channel: Lessons from the crisis. Economic Policy, 26(66), 135-182.

Gambacorta, L., Hofmann, B., \& Peersman, G. (2014). The effectiveness of unconventional monetary policy at the zero lower bound: A cross-country analysis. Journal of Money, Credit and Banking, 46(4), 615-642.

Garcia-Posada, M., \& Marchetti, M. (2016). The bank lending channel of unconventional monetary policy: The impact of the VLTROs on credit supply in Spain. Economic Modelling, 58, 427-441.

Girardin, E., \& Moussa, Z. (2011). Quantitative easing works: Lessons from the unique experience in Japan 2001-2006. Journal of International Financial Markets, Institutions and Money, 21(4), 461-495.

Güntner, J. H. (2015). The federal funds market, excess reserves, and unconventional monetary policy. Journal of Economic Dynamics and Control, 53, 225-250.

Hamada, K. (1995). 'Bubbles, bursts and bailouts: A comparison of three episodes of financial crises in Japan', in Okabe, M. (ed.), The Structure of the Japanese Economy: Changes on the Domestic and International Fronts (Basingstoke: Macmillan), 263-286

Hanisch, M. (2017). The effectiveness of conventional and unconventional monetary policy: Evidence from a structural dynamic factor model for Japan. Journal of International Money and Finance, 70, 110-134.

Hosono, K. (2006). The transmission mechanism of monetary policy in Japan: Evidence from banks' balance sheets. Journal of the Japanese and International Economies, 20(3), 380-405.

Iacoviello, M., Navarro, G. (2019) Foreign effects of higher U.S. interest rates. Journal of International Money and Finance, https://doi.org/10.1016/j.jimonfin.2018.06.012.

Joyce, M. A., \& Spaltro, M. (2014). Quantitative easing and bank lending: a panel data approach. Bank of England. Quarterly Bulletin, 54(3), 355.

Kashyap, A. K., \& Stein, J. C. (2000). What do a million observations on banks say about the transmission of monetary policy? American Economic Review, 407-428.

Kilian, L., \& Lütkepohl, H. (2017). Structural vector autoregressive analysis. Cambridge University Press.

Kimura, T., Kobayashi, H., Muranaga, J., \& Ugai, H. (2003, September). The effect of the increase in the monetary base on Japan's economy at zero interest rates: an empirical analysis. In Monetary Policy in a Changing Environment, Bank for International Settlements Conference Series (Vol. 19, pp. 276-312).

King, G., (1986). Monetary transmission: Through bank loans or bank liabilities? Journal of Money, Credit and Banking, 18: 290-303. 
Kishan, R.P., Opiela, T.P., (2000). Bank size, bank capital, and the bank lending channel. Journal of Money, Credit and Banking, 121-141.

Kishan, R.P., Opiela, T.P., (2006). Bank capital and loan asymmetry in the transmission of monetary policy. Journal of Banking and Finance, 30 (1), 259-285.

Kobayashi, T., Spiegel, M. M., \& Yamori, N. (2006). Quantitative easing and Japanese bank equity values. Journal of the Japanese and International Economies, 20(4), 699721.

Krishnamurthy, A., \& Vissing-Jorgensen, A. (2011). The effects of quantitative easing on interest rates: Channels and implications for policy. Brookings Papers on Economic Activity, 2011(2), 215-287.

Love, I., \& Ariss, R. T. (2014). Macro-financial linkages in Egypt: A panel analysis of economic shocks and loan portfolio quality. Journal of International Financial Markets, Institutions and Money, 28, 158-181.

Love, I., \& Zicchino, L. (2006). Financial development and dynamic investment behavior: Evidence from panel VAR. The Quarterly Review of Economics and Finance, 46(2), 190-210.

Matsuki, T., Sugimoto, K., \& Satoma, K. (2015). Effects of the Bank of Japan's current quantitative and qualitative easing. Economics Letters, 133, 112-116.

Michaelis, H., \& Watzka, S. (2017) Are there differences in the effectiveness of quantitative easing at the zero-lower-bound in Japan over time? Journal of International Money and Finance, 70, pp. 204-233

Nakajima, Z. \& Taguchi, H. (1995). 'Toward a more stable financial framework: Longterm alternatives - An overview of recent bank disruption worldwide', in Sawamoto, Nakajima and Taguchi, 41-98

Oda, N., \& Ueda, K. (2005). The effects of the Bank of Japan's zero interest rate commitment and quantitative monetary easing on the yield curve: A macro-finance approach (No. 05-E-6). Bank of Japan.

Okina, K., \& Shiratsuka, S. (2004). Policy commitment and expectation formation: Japan's experience under zero interest rates. The North American Journal of Economics and Finance, 15(1), 75-100.

Okina, K., Shirakawa, M, \& Shiratsuka, S. (2000). The asset price bubble and monetary policy: Japan's wxperience in the late 1980s and the lessons, Bank of Japan, Institute for Monetary and Economic Studies, Discussion Paper no. 2000-E-12

Olivero, M. P., Li, Y., \& Jeon, B. N. (2011). Competition in banking and the lending channel: Evidence from bank-level data in Asia and Latin America. Journal of Banking \& Finance, 35(3), 560-571.

Philippas, D., Papadamou, S., \& Tomuleasa, I. (2019). The role of leverage in quantitative easing decisions: Evidence from the UK. The North American Journal of Economics and Finance, 47, 308-324.

Ramos-Tallada, J. (2015). Bank risks, monetary shocks and the credit channel in Brazil: Identification and evidence from panel data. Journal of International Money and Finance, 55, 135-161. 
Schenkelberg, H., \& Watzka, S. (2013). Real effects of quantitative easing at the zero lower bound: Structural VAR-based evidence from Japan. Journal of International Money and Finance, 33, 327-357.

Shirakawa, M. (2002). One year under" quantitative easing". Institute for Monetary and Economic Studies, Bank of Japan.

Sims C. (1980), Macroeconomics and reality, Econometrica, 48(1), 1-48.

Stiglitz, J. E., \& Weiss, A. (1981). Credit rationing in markets with imperfect information. The American Economic Review, 71(3), 393-410.

Tobin, J. (1970). Deposit interest ceilings as a monetary control. Journal of Money, Credit and Banking, 2(1), 4-14.

Ugai, H. (2007). Effects of the quantitative easing policy: a survey of empirical analyses. Monetary and Economic Studies-Bank of Japan, 25(1), 1.

Van Rixtel, A. (2002). Informality and monetary policy in Japan: The political economy of bank performance. Cambridge University Press.

Wang, L. (2016). Unconventional monetary policy and aggregate bank lending: Does financial structure matter?. Journal of Policy Modeling, 38(6), 1060-1077.

Watanabe, T., \& Yabu, T. (2013). The great intervention and massive money injection: The Japanese experience 2003-2004. Journal of International Money and Finance, 32, 428-443.

Yang, J., \& Zhou, Y. (2013). Credit risk spillovers among financial institutions around the global credit crisis: Firm-level evidence. Management Science, 59(10), 2343-2359.

Yang, Z., \& Zhou, Y. (2016). Quantitative easing and volatility spillovers across countries and asset classes. Management Science, 63(2), 333-354. 